\title{
Kayseri Cumhuriyet Mahallesi Yaya Bölgesi Tasarımının İrdelenmesi Ve Kullanıcı Tercihlerinin Belirlenmesi
}

\author{
*Aslıhan ERDOĞAN' ${ }^{1}$ \\ ${ }^{1}$ Nevşehir Hacı Bektaş Veli Üniversitesi, Mühendislik-Mimarlık Fakültesi, Peyzaj Mimarlığı Bölümü, \\ Nevşehir, \\ *Sorumlu Yazar:aslihanerdogan@nevsehir.edu.tr
}

Geliș Tarihi:23.06.2015

\begin{abstract}
Özet
Yaya bölgesi, kentlerde yoğun motorlu araç ve yaya trafiğinin karmaşıklığının azaltılması amacıyla; yalnız yaya trafiğine açılan, yaya dolaşım ve alış-veriş merkezi güzergâhı olarak oluşturulan yol veya mekânlardır. Kayseri Cumhuriyet Mahallesi birçok sivil mimari, dini ve kültürel önemi olan yapıların bulunduğu tarihi kent merkezini oluşturan mahallelerden biridir. Özellikle tarihi kent dokusunun yeniden canlandırılması amacıyla yaya bölgelerini planlama ve tasarlama sürecine halk katılımının sağlanması önemlidir. Bu çalışmada Cumhuriyet Mahallesi yaya bölgesi düzenlemesi için kent halkı ve işyeri sahiplerinin yapılan düzenleme ile ilgili görüşleri, istekleri saptanmış ve mevcut durumun yeterliliği ortaya konulmaya çalışılmıştır. Kent halkına ve iş yeri sahiplerine yapılan iki farklı anket ile yaya bölgesi hakkındaki görüşleri değerlendirilmiştir. Kent merkezinde yaya bölgeleri oluşturulması ile ilgili soruya kent halkının \% 79,8'i, işyeri sahiplerinin ise \%55'i evet cevabını vermiştir. Sonuç olarak kentsel açıkyeşil alan sisteminin bir parçası olan yaya bölgelerine kent halkının ihtiyacı olduğu ortaya çıkmıştır.

Anahtar kelimeler: Kayseri, Yaya Bölgesi, Kentsel Peyzaj, Kullanıcı Tercihleri
\end{abstract}

\section{An Analysis of the Design of Kayseri Cumhuriyet Neighborhood Pedestrian Zone and Determining the Preferences of Users}

\begin{abstract}
The pedestrian area is a road or spaces where the places which only opened to pedestrian traffic, that created as a pedestrian circulation and shopping center in order to reduce motor vehicle and pedestrian traffic in dense urban areas complexity. Kayseri Cumhuriyet Neighborhood have many buildings of civil, religious and cultural architecture and it is one of the neighborhoods that make up the historical city center. Especially, it is important to incorporate public participation into the processes of planning and designing pedestrian spaces for the revitalization of historic urban fabric. In this study, the views and demands of users and owner of the businesses in the Cumhuriyet Neighborhood pedestrian zone design have been determined and have tried to reveal the adequacy of the current situation. Two different questionnaires have been applied taking the users and the shopkeepers opinions on pedestrian zone.79,8\% of the users and $55 \%$ of the owner of the businesses have approved the question on designing new pedestrian zones in the city center. As a result, the pedestrian zone, which is part of the urban open green space system has emerged as the needs of users.
\end{abstract}

Keywords: Kayseri, Pedestrian zone, Questionnaire, Urban landscape, Preferences of users

\section{Giriş}

Toplumun her kesiminden insanın sürekli etkileşim halinde bulunduğu kamusal alanlar, toplumsal kimliği şekillendiren en önemli öğelerden biridir (Onay, 2005).Kamusal diş mekanlar sisteminin yaklaşı1k \% 80'ini olușturan cadde ve sokaklar özel yașamın biterek kamusal yaşamın başladığ 1 ve günlük yaşamın büyük bölümünün geçtiği alanlardır (Özkan ve ark., 1993). Bu mekânlar; kent insanının ticari, ulaşım, rekreasyonel ve kültürel pek çok gereksinimlerini karşılayan önemli mekânlardır.

Hızlı nüfus artışıyla birlikte artan taşıt sayısı taşı yollarının genişletilmesine neden olmuştur. $\mathrm{Bu}$ durum yaya yollarında, yayaların konfor ve güvenliğinde sorunları ortaya çıkarmıştır. $\mathrm{Bu}$ nedenle yaya yoğunluğunun en fazla olduğu konut alanları, alış-veriş merkezleri ve kent merkezlerinin taşıt trafiğinden kısmen yada tümden arındırarak, kentliye rahatça kullanabileceği açık mekânlar sunma olanağı yaratılması önem taşımaktadır (Gültekin, 2007).

$\mathrm{Bu}$ amaçla yaya bölgesi kavramı ortaya çıkmış, hızla yaya bölgeleri planlamaya başlanmış ve zaman içerisinde yaya bölgeleri kentlerin önemli unsurları haline gelmiştir. Yaya bölgeleri, birden çok yaya yolu içeren, tarihi kent merkezlerinde yoğun motorlu araç ve yaya trafiğinin yavaşlatılarak yönlendirilmesi ile insanlara rahat ve güvenli 
hareket olanağı sunan, sosyal ve ekonomik hayatı canlandırmak amacıyla çeşitli işlevlerle donatılmış kentsel açık alanlardır. Kentsel peyzajın zenginleşmesi, ulaşıma yön vermesi, trafiğin azalması, tarihi değerlerin korunması, hava kirliliğinin azalması gibi faydalar sağlayan yaya bölgeleri, gün geçtikçe beton yığınları içerisinde sıkışan kent halkı için bir gereksinim halini almaktadır (Şişman ve Kırzıoğlu, 2002).

Yaya bölgeleri uygulamaları ilk defa1926 yılında B. Almanya'nın Essen eyaletinde bir sokağın yaya yoluna dönüştürülmesi ile gerçekleştirilmiştir. II. Dünya Savaşı'ndan önce ki bir diğer uygulama ise ABD'nin New York kentindeki Rockefeller Center'dır (Çağlar, 1992). Daha sonra 1940'lı y1llarda Hollanda ve Batı Almanya gibi Avrupa kentlerinde, 1960'lı yıllarda da Kuzey Amerika'da başlamıştır. Bu çalışmalar ile tarihsel karakterin korunması, gün boyu motorlu taşıt trafiği altında ezilen, geceleri terkedilen mekânların yaşatılması amaçlanmıştır. Ülkemizde ise 1970'li yıllardan sonra ilgi görmeye başlamış, ilk kez Ankara Belediyesi'nin 1978 yılında başlattığı yayalaştırma çalışmaları ile uygulamaya konulmuştur. Ülkemizde özellikle İstanbul, Bursa, İzmir gibi kentlerimizde alışveriş merkezi özelliğindeki Kapalı Çarşı ve Kemeraltı gibi mekânlar, uzun süreden beri, gerek sosyal, gerekse ekonomik açıdan yaya bölgesi olarak kullanılmaktadırlar (Zafer, 1998).

Yaya bölgeleri, kent merkezinde cadde ve sokakların birleştirilmesiyle yayaların daha fazla zaman geçirebileceği mekanların en başında gelmektedir (Robertson, 1999). Yaya bölgelerinin insan davranışları üzerinde üç temel etkiye sahiptir. Bunlar korunaklı mekan, güven ve mesafelerin azaldığ algisidır (Lorch ve Smith, 1993). Yayalaştırma uygulamaları ile özellikle tarihi kent merkezlerinde kentsel kimliğe olumlu katkıların sağlanması ve toplumsal aktivitelere olanak oluşturulması hedeflenir. Gülersoy, (1992)'ye göre yayalaştırma uygulamalarında temel hedefler; tarihi geleneksel dokuyu korumak, kentsel imaj kalitesini yükseltmek, kentte nirengi noktaları oluşturmak ve trafiğgin olumsuz etkilerinden uzak bir mekân oluşturmaktır.

Gün geçtikçe beton yığınları içerisinde sıkışan kent halkı için bir gereksinim halini alan yaya bölgelerinin düzenlenmesinde ilk ele alınması gereken konu, uygun yerin seçimidir. Yer seçiminde özellikle transit ve yoğun trafiğin olmadiğı konut bölgeleri arasındaki tali yollar, yada yaya yoğunluğunun fazla olduğu kent merkezindeki alışveriş bölgeleri ile tarihsel önemi olan kentsel sit alanlarına öncelik verilir (Bayraktar vd., 1987). Yaya bölgeleri planlama ve tasarımlarında dikkat edilmesi gereken ilkeler Tablo 1'de verilmiştir (Rubenstein, 1992, Çağlar 1992, Zafer 1996 ).

Kayseri ili tarihi kent dokusu içerisinde yayalar için düzenlenmiş birbiri ile ilişkili farklı mekânlar bulunmaktadır. Bunlardan biri olan Cumhuriyet Mahallesi, yapilan yayalaştırma çalışması ile özellikle alışveriş mekânlarında halkın rahatlıkla gezebileceği, oturup dinlenebileceği mekânlara kavuşturulmuştur.

$\mathrm{Bu}$ çalışmanın amaci; tarihi kent merkezi içerisinde yer alan Cumhuriyet Mahallesi Yaya Bölgesi'ndeki planlama ve tasarım uygulamalarının ne ölçüde başarılı olduğunun ortaya konması, halkın ihtiyaçlarına ne ölçüde cevap verebildiğinin belirlenmesi, toplumsal aktivitelerde ve kentsel planlamadaki öneminin vurgulanmas1, yaya bölgesindeki temel sorunların ve eksikliklerin belirlenerek bunlara ilişkin çözüm önerilerinin getirilmesidir. 
Tablo 1. Yaya bölgeleri planlama ve tasarım ilkeleri ((Rubenstein, 1992, Çağlar 1992, Zafer 1996 )

\begin{tabular}{lll}
\hline Planlama İlkeleri & Tasarım ilkeleri & \\
\hline Uygun yer seçimine dikkat edilmelidir & $\begin{array}{l}\text { Döşeme için uygun malzemeler seçilmeli, } \\
\text { rahat yürümeyi engellememeli ve kaygan } \\
\text { olmamalıdır }\end{array}$ \\
\hline $\begin{array}{l}\text { Uygulama tamamlandı̆̆ı zaman çevre mimarisinden } \\
\text { kopmamalı dolayısıyla kentsel strüktürün bütünlüğü } \\
\text { bozulmamalıdır }\end{array}$ & $\begin{array}{l}\text { Özgün ve nitelikli donatı elemanları } \\
\text { kullanılmalıdır }\end{array}$ \\
\hline Halk katılımı sağlanmalıdır & Aydınlatma yeterli düzeyde olmalıdır \\
\hline $\begin{array}{l}\text { Kentsel ulaşımdan koparılmamalı birbirleriyle ilişkili } \\
\text { olmalıdır }\end{array}$ & $\begin{array}{l}\text { Giriş ve çıkışı belirgin ve açı olarak } \\
\text { tanımlanmalıdır }\end{array}$ & $\begin{array}{l}\text { Yaya bölgesini yaşatacak eğlence, kültür, } \\
\text { Spor, sanat etkinliklerine olanak verecek } \\
\text { Sinılarla belirlenen ayrı bir kimliğe sahip olmalıdınlar olușturulmalıdır }\end{array}$
\end{tabular}

Toplu taşıma ve kolay ulaşılabilirlik olanaklarına sahip olmalıdır

İlgi çekici su öğeleri ve plastik elemanlara yer verilmelidir

Yeterli otopark olanaklarına sahip olmalıdır

Yeterli sayı ve özellikte oturma mekanları olmalıdır

\section{Materyal ve Yöntem}

Materyal

Kayseri kent merkezi, şehrin bütün ulaşım ağlarının toplandığı ve dağıldığı, ışınsal bir kent dokusuna sahiptir. Araştırma alanı olarak, Kayseri tarihi kent merkezinde yer alan Cumhuriyet Mahallesi Yaya Bölgesi seçilmiştir.

Cumhuriyet Mahallesi birbirine paralel ve birbirini kesen ana ve ara yolların birleşmesiyle oluşan fiziksel bir yapıya sahiptir. Ana ve ara sokaklar ticari potansiyeli yüksek, bitișik nizamdaki ticari dükkânlar, mağazalar ve iş merkezleri ile sinırlandırılmıştır. Ayrıca çok sayıda büro, banka, eczane, kuyumcu vb. bulunmaktadır. Kent merkezinde bulunan ve yoğun olarak kullanilan Cumhuriyet Mahallesi, 2003 yılında yaya bölgesi olarak düzenlenmiştir. Toplam $36000 \mathrm{~m}^{2}$ 'lik alanı kapsayan çalışma alanı, Kayseri'nin en eski ve işlek alışveriş merkezi olan çarşı içini kapsamaktadır.

Cumhuriyet Mahallesi Yaya Bölgesi Kayseri'de ilk ve tek yaya bölgesi uygulamasıdır. 27 Mayıs ve Nazmi Toker Caddelerinde transit geçişin izin verildiği, taşıt trafiğine tamamen kapalı yaya yolları siniflandırılmasina ait bir yaya bölgesi örneğidir. Ayrica yaya bölgesi tarihi kent
Motorlu araç trafiğinin yaya trafiği ile kesiştiği durumlarda yaya yolu da alçaltılmalıdır

merkezinde aşağıdaki özellikleri ile de önem taşımaktadır;

- Kayseri'nin eski alışveriş merkezini (Çarşı içi) oluşturması ve ticari potansiyeli yüksek büro, restoran, eczane, kuyumcu, banka, vb. birçok dükkân ve mağazanın bulunması,

- Sivil mimari, dini ve kültürel önem taşıyan yapıların yer alması ( İmamzade Reşit Ağa Konağ1, Güpgüpoğlu Konağı, Cıncıklı Camii, Aya Nikola Kilisesi, Şeyh Tennuri Türbesi, Emir Sultan Türbesi, Sultan Hamami),

- Yaya bölgesinin kent meydanına (Cumhuriyet Meydanı) yakın olması,

- Kayseri Kalesi, Hunat Hatun Camii ve Külliyesi, Kapalı Çarşı ve Vezir Hanı gibi tescilli birçok tarihi ve kültürel yap1 örneklerinin oluşturduğu tarihi kent merkezinde olmas1,

- Kent merkezindeki tarihi dokuyla bağlantı kuran, önemli yoğunluktaki aksların birleşim koridoru olmasıdır.

Çalışmanın ana materyalini Cumhuriyet Mahallesi yaya bölgesini oluşturan; Nazmi Toker, Serdar, Kizilay, Turan, Vatan, Sur, Mevlevi, Tennuri, Sultan Hamam, Kizılay, Turan Caddeleri ile Aydınlık, Emir Sultan, 
Aytar, Çevik, Umur ve Faraşoğlu Sokakları ile yaya bölgesi kullanıcıları (kent halkı ve iş yeri sahipleri) oluşturmaktadır (Şekil 1).

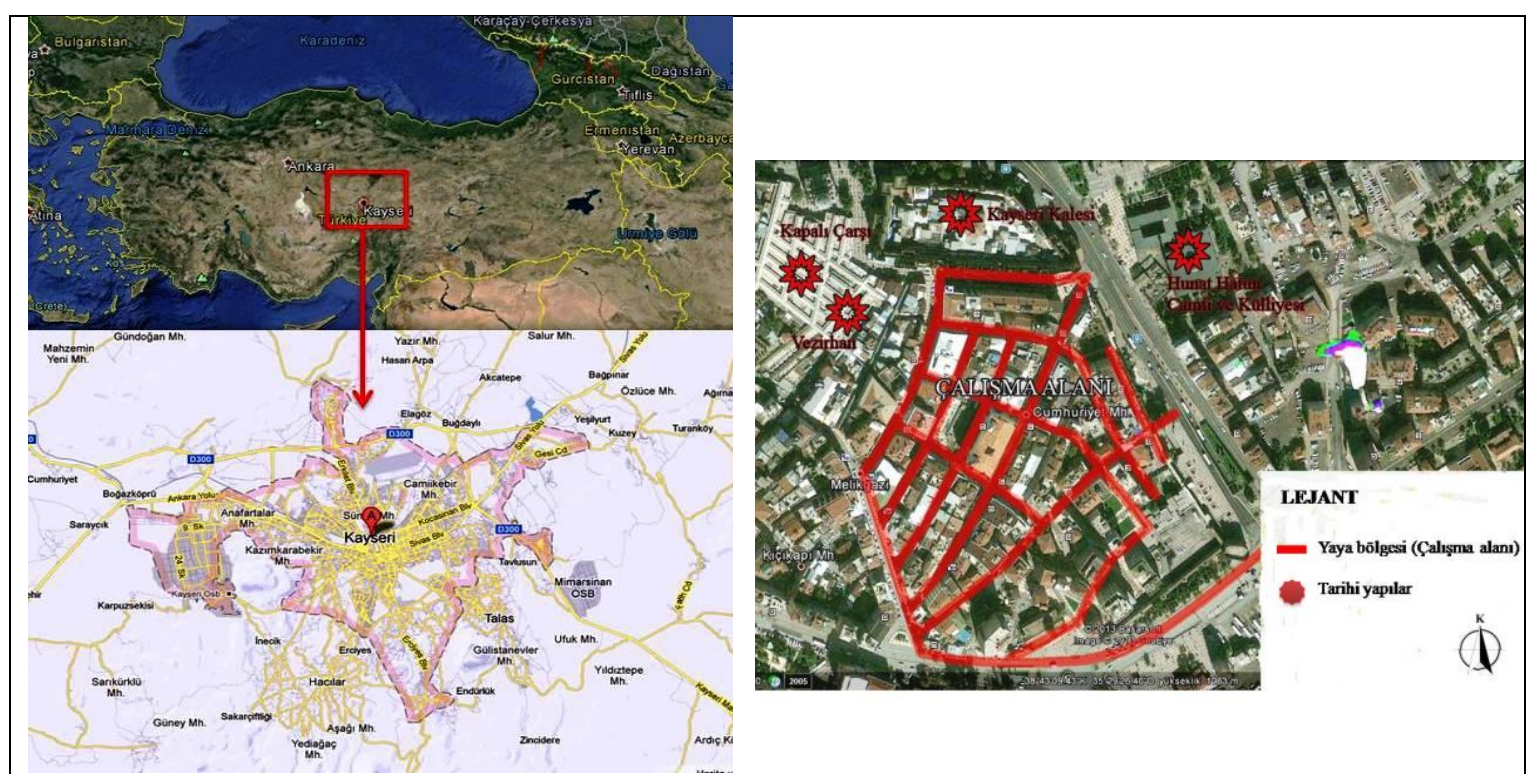

Şekil 1. Kayseri’nin genel konumu ve Kayseri Kenti Cumhuriyet Mahallesi Yaya Bölgesi'nin konumu

\section{Yöntem}

Çalışma, konuya ilişkin verilerin elde edilmesi, arazi çalıșması ile mevcut durumunun analizi, anketlerin oluşturulması ve anket çalışmasının yapılması, sonuçların değerlendirilmesi ve öneriler olmak üzere 4 aşamada gerçekleştirilmiştir.

Birinci aşamada çalışma alanı ve konusuna yönelik verilere elde edilmiş yapılan arazi çalışması ile alanın mevcut durumu analiz edilmiştir.

İkinci aşamada elde edilen veriler ışığında, kent halkı ve bu bölgede bulunan işyeri sahiplerine yapılmak üzere farklı iki adet standart anket formu hazırlanmıştır. Anketlerde yayalar için kısa, öz ve anlaşı1lır nitelikte yayalar için toplam 10adet, işyeri sahipleri içinse toplam 9 adet soru sorulmuştur.

Üçüncü aşamada her iki grup için hazırlanan anket formu farklı yaş, cinsiyet ve meslekten 100 kişiye yüz yüze görüşme şeklinde uygulanmıştır. Anket çalışması ile yaya bölgesinin kent halkının ve iş yeri sahiplerinin ihtiyaçlarına ne ölçüde cevap verebildiği, Cumhuriyet Mahallesi yaya bölgesi planlama ve tasarımının ne ölçüde başarılı olduğu hakkında düşünceleri sorulmuştur. Anket çalışmasının değerlendirilmesinde ki-kare analizi ve LSD çoklu karşılaştırma testi uygulanmıştır.

Dördüncü ve son aşamada anket verileri değerlendirilerek yaya bölgesinin temel sorunları, eksiklikleri belirlenmiş ve bunlara ilişkin çözüm önerileri getirilerek yaya bölgelerinin kentsel planlamadaki önemi vurgulanmıştır.

\section{Bulgular}

Kayseri Kent'inde kentsel yaşamı şekillendiren sosyal, kamusal ve ticari işlevleri içeren ve tarihi kent dokusuna sahip Cumhuriyet Mahallesi Yaya Bölgesi önemli yoğunluktaki aksların birleşim koridoru olması ve yaya yoğunluğunun fazla olması bakımından konum olarak uygun kriterleri içermektedir. Eski alış-veriş merkezi (Çarşı içi) olması nedeniyle Cumhuriyet Mahallesi Yaya Bölgesi yayalar için bir cazibe merkezidir. Ayrıca yaya bölgesinin tarihi kent meydanına yakın olması ve alanda tarihi yapıların bulunması da alanın işlevini artırmaktadır.

Cumhuriyet Mahallesi Yaya Bölgesinde çok sayıda ticari potansiyeli yüksek büro, 
yeme-içme mekânı, eczane, kuyumcu, banka vb. birçok dükkân ve mağaza bulunmaktadır. $\mathrm{Bu}$ nedenle yaya trafiğinin yoğun olduğu ve kentin yoğun kullanılan kentsel açık mekânıdır. Yaya bölgesi insanların alışveriş dışında iş veya okulları nedeniyle zorunlu geçiş yaptıkları bir alandır.

Yaya bölgesinde 27 Mayıs ve Nazmi Toker Caddeleri dışında araç giriş çıkışı trafiğe kapatılmıştır. Yaya bölgesi yakın çevresinde açık ve kapalı otopark alanının az sayıda olmasi nedeniyle kullanıcilar araçlarını bu caddeler üzerine park etmektedir. $\mathrm{Bu}$ durum hem trafik akışını yavaşlatmakta hem de yayaların güvenliğini tehdit etmektedir.

Alanda ve yakın çevresinde birçok tarihi ve kültürel yap1 bulunmaktadır. Yaya bölgesinde bulunan mevcut iş yerlerinin cephe yüzeyleri farklılıklar göstermekte, işletme tabelaları ve vitrinlerdeki çeşitlilik görüntü kirliliği oluşturmaktadır.

Yaya bölgesi genelinde herhangi bir bitkilendirme çalışmasının yapılmadığı sadece bitki kasalarında mevsimlik çiçeklerin ve Thujaorientalis 'CompactaAureaNana', Piceaglauca 'Conica' gibi çalı gruplarının kullanıldığg gözlemlenmektedir (Şekil 2).
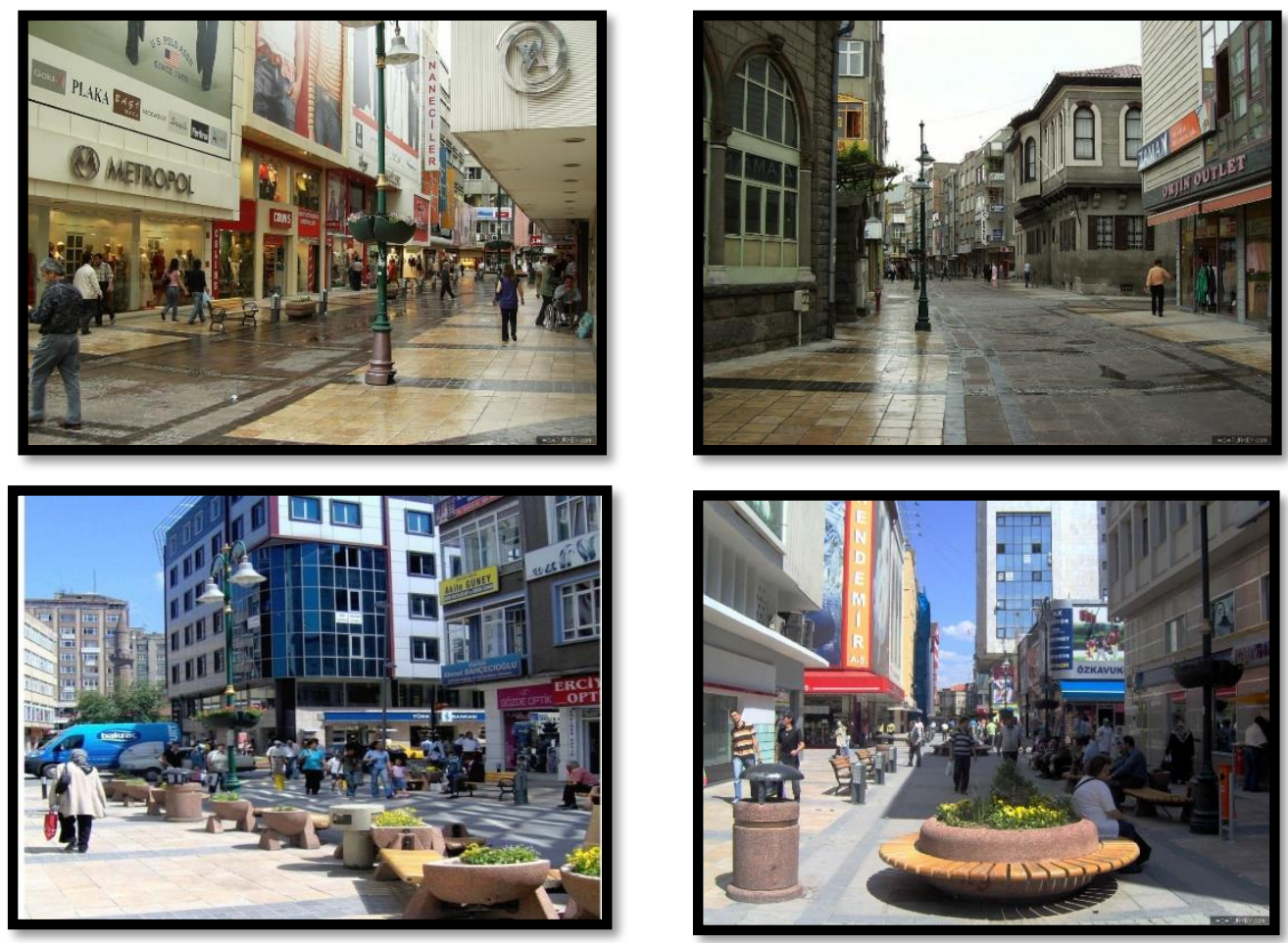

Şekil 2. Cumhuriyet Mahallesi yaya bölgesinden görünümler

\section{Kent Halkı İle Yapılan Anket Çalışmasına İlişkin Bulgular}

Karşılıklı yapılan anket çalışmasında öncelikli olarak kişilere, kişilerin bireysel özelliklerinin belirlenmesine yönelik sorular sorulmuştur. Anket sonucu ankete katılan kullanıcıların cinsiyet dağılımının \%57'sini erkekler, \%43'nü bayanlar oluşturmaktadır. Yaya bölgeleri taşımış oldukları estetik ve fonksiyonel özellikleri ile kullanıcıların taleplerine cevap verecek nitelikte olmalıdir. $\mathrm{Bu}$ talepler kişilerin eğitim seviyesine ve yaş gurubuna göre farklılıklar gösterebilmektedir. $\mathrm{Bu}$ amaçla anket farklı yaş ve meslek gurubundan, farklı eğitim seviyesine sahip bireyler arasında gerçekleştirilmiştir. Ankete katılanların \%2'si 18 ve alt1, \%40'1 18$30, \% 57$ 'si $30-60$ ve $\% 1$ 'i 60 ve üzeri yaş gurubundandir. Ayrica $\% \quad 11$ 'nin ilkokul, \%16'sının lise, \%68'inin üniversite ve \% 5'inin yüksek lisans mezunu olduğu belirlenmiştir.

Yüz yüze yapılan anket değerlendirmesi sonucu bireylerin yaya bölgesinden 
yararlanma amaçları belirlenmeye çalışılmıştır. Bireylerin yaya bölgesinden yararlanma amacı ve zamanları mesleklerine göre farkl1lı göstermektedir. Günün belirli saatlerinde çalışan memur, işçi vb. meslek gruplarının \% $54,8^{\prime}$ inin bölgeden yararlanması ișe gidiș ve çıkış saatlerinde geçiş amaçlı iken; ev hanımı, öğrenci vb. çalışmayan kesimin\%63,6'sının ise yaya bölgesinden günün herhangi bir saatinde geçiş amaçlı ya da alışveriş yapmak için yararlandıkları belirlenmiştir.

Kent merkezinde bulunan Cumhuriyet Mahallesi yaya bölgesine kullanıcıların \%44'ününözel aracını, \%19'unun toplu ulaşım araçlarını kullanarak, \% 37'sinin ise yaya olarak alana ulaştığ 1 tespit edilmiştir. Yaya bölgesinin kent merkezinde olması, uzak mahallelerde oturan bireylerin daha çok özel araç ve toplu ulaşım araçlarını, yakın mahallelerde oturanların ise yaya ulaşımını tercih etmelerine neden olan bir etkendir. Ayrica kullanıcıların gelir düzeyi de ulaşım tercihlerini etkilemektedir. Ücretli çalışanların \%47,9'u özel araçları ile ulaşımı, çalışmayanların \%63,6'sı yaya ulaşımını tercih ettiği belirlenmiştir. Ulaşımda özel araçların tercih edilmesi sonucu çarşı içindeki araç yoğunluğu artmakta ve otopark sorunu ortaya çıkmaktadır. Katılımciların \%60'1 kent merkezindeki otoparkların yetersiz, \%40'1 ise yeterli olduğunu söylemiştir.

Trafiğe kısmen kapatılarak olușturulan yaya bölgesi, oluşturduğu güvenli ve rahat mekânlar ile insanların rekreasyonel ihtiyaçlarını karșılamaktadır. Ayrıca kullanıcılara güvenli ulaşım, gezinti ve alışveriş imkanı sağlamakta, daha önce fark edemedikleri ve algılayamadıklarını fark etme ve algilama olanăg vermektedir. Cumhuriyet Mahallesinin yaya bölgesi olarak kullanılmaya başlanması ile birlikte kullanıciların \%14.3'ü yaya bölgesi sayesinde alanda daha önce fark etmedikleri șeylerin farkına vardıklarını, \% 58.3'ü alanda artık daha rahat yürüdüklerini ve \% 27.4'ü ise kendilerini alanda daha güvende hissettiklerini belirtmişlerdir.

Kent içinde yayaların rahat dolaşıp, rekreatif faaliyetler gerçekleştirebileceği güvenilir mekânlara ihtiyaç vardır. Kent merkezinde yayalar için yapılan bu düzenlemeden ankete katılanların \%79.8'i memnun iken \%20.2'si ise memnun olmadığını dile getirmiştir. Yapılan bu düzenleme ile kullanıcıların \%39.3'ü alanda rahat alış veriş yapabilme imkanı buldukların1, $\% 47.6$ 's1 güvenle dolaşabildiklerini, \% 8.4'ü çarşı içinde ulaşım sorununun arttığını ve \% 4.7'si kent merkezinde egzoz dumanlarından kaynaklı kirliliğin azaldığını ifade etmişlerdir.

Yaya bölgeleri tasarım kriterleri doğrultusunda tercih edilen doğru ve yeterli kent mobilyaları ile yaya bölgelerinde estetik ve fonksiyonel mekânların yaratılması mümkündür. Ankete katılanların \%13.1'i su öğesi, \%50'si yeşil alan, \%36.9'u ise donatı elemanları ile alanın zenginleştirilmesi, daha estetik hale getirilmesi gerektiğini ifade etmiştir (Şekil 3).

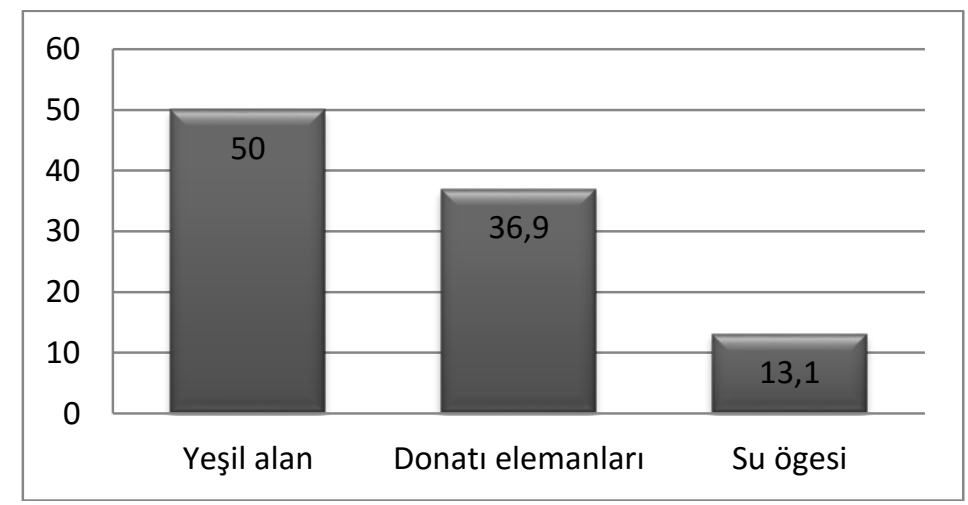

Şekil 3.Yaya bölgesinde eksikliği hissedilen donatıların yüzde dağılımı 
Ayrica yapılan ki-kare analizinde yaya bölgesinde olması istenilen donatılar eğitim seviyesine göre farklılığın istatistiki anlamda önemli olduğu belirlenmiştir $(\mathrm{p}<0,01)$.Illkokul mezunu kullanıcılar donatı elemanlarının artırılmasını isterken üniversite mezunları yeşil alan varlığının artırılmasını istemiştir.

Yaya bölgesinde yollarda kullanılan döşeme malzemeleri gerek rengi, gerek dokusu ile alanı tanımlamakta ve yayaları yönlendirmektedir. Fakat ankete katılanların \% 53.6's1 yaya bölgesinde kullanılan döşeme malzemesinin kullanışsız olduğunu, \%46.4'ü ise kullanışlı olduğunu belirtmişlerdir.
Toplumu oluşturan insanların eğitim seviyelerine bağlı olarak rekreatif istekleri de değişmektedir. İlkokul mezunu kullaniciların $\quad \% 88.9^{\prime} \mathrm{u}, \quad$ lise mezunlarının \%42.9'u ve üniversite mezunlarının \%36.1'i yaya bölgesinde her hangi bir faaliyetin gerçekleştirilmesini istemezken, ilkokul mezunu kullaniciların $\quad \% 11.1$ 'i, lise mezunlarının $\% 57.1$ 'i ve üniversite mezunlarının \%63.9'u bu alanın kafe ve canlı müzik gibi uygulamalarla gece de kullanılmasını istediğini ifade etmiştir (Şekil 4).

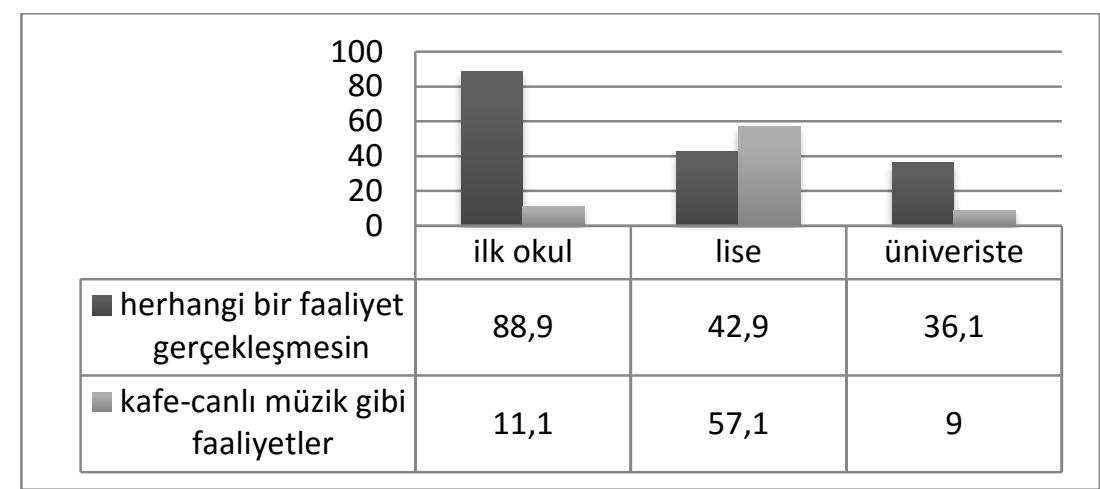

Şekil 4.Ankete katılanların yaya bölgesinde olmasını istedikleri rekreatif isteklerin yüzde dağılımı

Cumhuriyet Mahallesinin yaya bölgesi olarak araç trafiğine kapatılma nedeninin ne olabileceği sorusuna kullanıcıların \%61.9'u rahat ve güvenli alış veriş, \% 17.9 'u trafik sorununu çözmek, \%20.2'si ise diğer görüşündedir. Kayseri Cumhuriyet Mahallesi

İş Yeri Sahipleri ile Yapılan Anket Sonuçlarının Değerlendirilmesi

İkinci anket çalışması yaya bölgesi çevresindeki Nazmi Toker, Serdar, Kızılay, Turan, Vatan, Sur, Mevlevi, Tennuri, Sultan Hamam, Kizılay, Turan Caddeleri ile Aydınlık, Emir Sultan, Aytar, Çevik, Umur ve Faraşoğlu Sokağı üzerinde yer alan 100 adet işyeri sahipleri ve çalışanları ile karşılıklı görüşülerek yapılmıştır.

Yaya bölgelerinin oluşturulmasında işyeri sahiplerinin istekleri ve bu düzenlemeye olan destekleri alanın sürekliliğinin sağlanmasında önemli bir unsurdur. Yapılan bu düzenleme sonucu iş yeri sahiplerinin $\% 55^{\prime} \mathrm{i}$ olumlu, $\% 45^{\prime} \mathrm{i}$ ise yaya bölgesinde; 27 Mayıs ve Nazmi Toker Caddelerinde transit geçişe izin verilmektedir. Kullanıcıların \%75'i bu caddelerinde trafiğe kapatılarak kent merkezinin araç işgalinden arındirılmasını isterken \%25'i kapatılmamasinı istemiştir. olumsuz yönde işlerinin etkilendiğini belirtmiştir. ̇̇şyeri sahiplerinin \%90'1 alandaki yaya sirkülasyonun rahat olduğunu ifade ederken, yaya sirkülasyonundaki bu rahatllk ve devaml1lık ile birlikte \%31'i müşteri sayılarının arttığını, \%43'ü azaldığını ve \%26'sı ise değişmediğini dile getirmiştir.

Yaya bölgesinde otoparkın büyük bir sorun olduğu görülmüştür. Park eden araçların ne kadarının işyeri sahiplerine ait olduğunun tespiti amacı ile iş yeri sahiplerinin alana ulaşım şekli araştırılmıștır. Ankete katılan iş yeri sahiplerinin \%62'si özel aracı ile \%38'i ise toplu ulaşım araçlarını kullanarak alana ulaştıklarını ifade etmişlerdir. 
Yaya bölgeleri sadece gündüzleri insanların alış veriş yapabildiği, rahat ve güvenli bir şekilde dolaşabildiği alanlar olmasının yanında gecede farklı kültürel aktiviteler ile aktif kullanılabilmektedirler. $\mathrm{Bu}$ alanın kafe ve canlı müzik gibi uygulamalarla gece de kullanıl malımı sorusuna işyeri sahiplerinin \%40'1 evet derken $\% 60$ ' 1 ise hayır demiştir. Fakat bu durum işyeri sahiplerinin eğitim seviyesine

Yaya bölgelerinde yayaların olduğu kadar işyeri sahiplerinin de günlük rekreasyonel isteklerine cevap verecek nitelikte estetik ve fonksiyonel mekânlar olușturulmalıdır. İşyeri sahiplerinin \%80'i alanda kullanılan döşeme malzemesinin fonksiyonel olmadığını belirtmiş, özellikle kış aylarında büyük tehlikeler oluşturduğunu söylemiştir. Eğitim seviyelerine bağlı olarak alanda olmasını istedikleri birimler farklılık göstermektedir. İlkokul mezunlarının \%66.7'si oturma birimlerinin artırılmasını, üniversite

İş Yeri Sahipleri ve Halkın Ortak Sorulara Verdiği Cevapların Karşılaştırılması

Alana ulaşım şekliniz nedir sorusuna her iki grubun verdiği yanıtlar arasındaki farklılığın istatistiki anlamda 0.01 seviyesinde önemli olduğu belirlenmiştir. Alana ulaşım şekliniz nedir sorusuna iş yeri sahiplerinin \%62'si özel aracını, \%38'i toplu ulaşım araçlarını kullandığını ifade ederken; kent halkının \%44'ü özel aracını, \%19'u toplu ulaşım araçlarını kullanarak ve \%37'si yaya ulaşımını tercih ettiğini ifade etmişlerdir.

Alanda bulunmasını istediğiniz birimler nedir sorusuna her iki grubun verdiği yanıtlar arasındaki farklılı̆̆ın istatistiki anlamda 0.05 seviyesinde önemli olduğu belirlenmiștir. İș yeri sahiplerinin \%41.7'si donatıların artırılmasını, $\% 38.10$ 'u yeşil alanların oluşturulmasını, \%17.9'u ise su öğelerine yer verilmesini belirtirken; kent halkının \%50'si yeşil alanların oluşturulmasını, \%36,9'u donatıların artırılmasını, \%13.1'i ise alanda su öğelerine yer verilmesini belirtmiştir.

Alanın tasarımında kullanılan döşeme malzemesi uygun mudur sorusuna her iki grubun verdiği yanıtlar arasındaki farklılığın istatistiki anlamda 0.00 seviyesinde önemli olduğu belirlenmiştir iş yeri sahiplerinin $\% 80$ 'i hayır cevabını bağlı olarak önemli derecede farklıl1k göstermiştir. İlkokul mezunu işyeri sahiplerinin \%83.3'ü istemez iken üniversite mezunlarının \%59.3'ü alanın gecede kullanılmasını istemektedir. İş yeri sahiplerinin \% 40'1 yaya bölgesinde yapilacak yeni uygulamalar ile daha estetik hale getirilmesiyle $\% 60$ ' 1 ise alanın tekrar trafiğe açılmasıyla müşteri sayılarının artabileceğini belirtmişlerdir. mezunlarının \%44.4'ü de yeşil alan miktarının artırılmasını istemiştir.

Transit geçişin izin verildiği Nazmi Toker ve Millet Caddesi'nin de araç trafiğine kapatılarak yaya bölgesi alanına dahil edilmesi önerisi işyeri sahiplerinin eğitim seviyesine göre farklılık göstermiş; ilkokul mezunu işyeri sahiplerinin \%83.3'ü caddelerin araç trafiğine kapatılmasını istemez iken üniversite mezunlarının \%59.3'ü kapatılması gerektiğini ifade etmişlerdir. verirken \%20'si evet cevabını vermiştir. Kent halkının \%53.6's1 hayır cevabını verirken \%46.4'ü evet cevabını vermiştir.

Alanın araç trafiğine kapatılmasından memnun musunuz sorusuna her iki grubun verdiği yanıtlar arasındaki farklılığın istatistiki anlamda 0.01 seviyesinde önemli olduğu belirlenmiştir. İşyeri sahiplerinin $\quad \% 55$ ' $\mathrm{i}$ memnun olmadığını , \%45'i ise memnun olduğunu ifade ederken kent halkının \%79.8'i memnun olduğunu, \%20.2'si memnun olmadığını ifade etmiştir.

27 Mayıs ve Nazmi Toker Caddelerinin de araç trafiğine kapatılmasını ister misiniz sorusuna; her iki grubun verdiği yanıtlar arasındaki farklılı̆gın istatistiki anlamda 0.00 seviyesinde önemli olduğu belirlenmiștir İşyeri sahiplerinin \%60'1 evet \%40'1 hayır cevabını verirken kent halkının \%75'i evet \%25'i hayır cevabını vermiștir.

Alanın canlı müzik-kafe gibi uygulamalarla gece de kullanımını ister misiniz sorusuna; her iki grubun verdiği yanıtlar arasındaki farklılığın istatistiki anlamda 0.01 seviyesinde önemli olduğu belirlenmiştir. İş yeri sahiplerinin \%80'i evet, \%20'si hayır cevabını verirken kent halkının \%57.1'i, evet \%42.9'u hayır cevabını vermiştir. 


\section{Tartışma ve Sonuc}

Kentler; insanların hem ruhsal hem de fiziksel olarak rahatlayabileceği, gezip eğlenebileceği rekreasyon alanları içeren mekânlar oluşturularak daha da yaşanabilir alanlara dönüştürülmelidir. Özellikle ticari aktivitelerin ve yaya trafiğinin yoğun olduğu alanlar, tarihi doku gibi önemli kriterlerin temelinde oluşturulan yaya bölgeleri;

ını kolaylaştırmak, rekreasyonel faaliyetlere mekân oluşturmak, bölgedeki tarihi doku ile de bağlantı kurmanın dışında kent sağlığ açısından da hayati önem taşımaktadır (Şenkaynak, 2010). Dolayısıyla kent bütünü içinde yaşam kalitesini artırıcı, bireyler arası ilişkileri güçlendirici kentsel mekânların bir parçası olan yaya bölgelerinin tasarımına öncelik verilmelidir.

Çalışmada kullanıcıların Kayseri Cumhuriyet Mahallesi Yaya Bölgesi hakkındaki görüşlerini, kullanıcıların ihtiyaçlarına ne ölçüde cevap verebildiğini ve kullanım amaçlarını belirlemek amacıyla daha önceki çalışmalar incelenmiş (Cengiz 2011, Şişman ve Uyguner 2009, Yıldırım vd. 2002) ve anket çalışması yapılmıştır. Alanda yapılan gözlemler ve anket çalıșması sonucu elde edilen veriler doğrultusunda yaya bölgesinde kullanıcıların rahat dolaşımını engelleyen bazı eksiklikler olduğu belirlenmiştir.

Yaya bölgelerinde kullanılan döşeme kaplaması renk ve desen oluşturma özellikleri ile yayaları yönlendirir. Yapılan anket çalışması sonucu Cumhuriyet Mahallesi Yaya Bölgesinde kullanılan döşeme malzemesi ile oluşturulan desenin yayaları yönlendirebildiği fakat tercih edilen malzeme türü nedeniyle kış aylarında kayganlaşan zeminin yaya trafiğini aksattığ ve yayalar için tehlike arz ettiği tespit edilmiştir. Bu nedenle özellikle kış aylarında yaya bölgesinde tuzlama ve temizleme işlemleri düzenli bir şekilde yapılarak yaya trafiğinin akışı sağlanmalıdır. Cengiz (2011) yaptığı çalışmada kullanıcıların \%27'sinin yaya bölgesinde kullanılan döşeme elemanlarının uygun olmadığını \%73’ü ise uygun olduğunu belirtmiştir. Şişman ve Uyguner (2009) yaptıkları çalışmada kullanıcıların \%37'sinin döşeme elemanlarını yeterli, \%63'nün ise yetersiz bulduğunu belirtmiștir.
Şişman ve Uyguner (2009) yaptığı anket çalışmasında kullanıcıların \%23'nün çöp sepetlerini, \%23'nün çiçekleri, \%20'sinin aydınlatma elemanlarını, \%20'sinin oturma birimlerini, \%14'nün telefon kabinlerini yetersiz bulduğunu tespit etmiştir. Yapılan çalışmada da benzer sonuçlar elde edilmiştir. Ankete katılanların \%13.1'i su öğesi, \%50'si yeșil alan, \%36.9'u ise donatı elemanları ile alanın zenginleştirilmesi, daha estetik hale getirilmesi gerektiğini ifade etmiştir. Ayrıca Yaya bölgesindeki yer 1zgaraları, çöp kutusu, aydınlatma elemanları, banklar vb. donatı elemanları gibi mevcut birimlerin etrafi engellileri uyarıcı şekilde kaplanmalı ve alanda yapılacak hissedilebilir zemin uygulamaları ile engelli kullanıcılar yönlendirilmelidir.

Yapılan anket çalışmasında kullanıcıların daha önce fark etmediklerini görmeye başlaması önemli bir sonuçtur. Fakat iş yeri sahiplerinin \%43'nün " müşteri sayılarında azalma" ile belirttikleri olumsuzluğun kaynağının üzerinde durulmalı ve müşteri sayılarının artırılmasına yönelik politikalar üretilmelidir.

Cengiz (2011) yaptığı çalışmada kullanıcıların \%87'sinin yaya bölgesi ve çevresi için ciddi bir otopark sorunu olduğunu \%13'nün ise olmadığını ifade etmiştir. Yapılan anket sonuçları değerlendirildiğinde gerek yayalar gerekse işyeri sahiplerinin transit geçiş yolları olan 27 Mayls ve Nazmi Toker Caddesi üzerindeki trafik yoğunluğundan rahatsız olduğu ve otoparkları yetersiz bulduğu belirlenmiştir. $\mathrm{Bu}$ nedenle yaya bölgesi ve çevresinde otopark sorununun yaşanmaması için halk çevredeki kapalı otoparkları kullanması yönünde bilinçlendirilmelidir.

Kültürel ve sanatsal etkinliklere olanak sağlayacak, yaya bölgesi genelinde faaliyet seviyesini arttırıcı fakat yaya dolaşımını engellemeyecek küçük satıcı kulübeleri, satış sergileri, açık alan yemek yeme yerleri ve kafeleri ile cadde üzerinde sokak sanatçılarının sanatsal faaliyetleri teşvik edilerek kentin kültürel gelişimine katk1 sağlanmalıdır.

Kullanıcıların daha fazla zaman geçirmeleri ve dinlenmeleri amaciyla oluşturulan oturma mekânları bitkisel materyallerle desteklenmeli ve yol kenarı 
bitkilendirme çalışmalarına önem verilmelidir. $\mathrm{Bu}$ bağlamda mekân etkisi yaratmak amaciyla yukardan dallanan, kaligrafik özelliğe sahip, gerek çiçeği gerek yaprak rengi ile etkili yaprak döken veya herdem yeşil ağaç / ağaççı türleri kullanılarak yaz aylarında insanların gölgesinden de yararlanabileceği ağaç altı oturma alanları oluşturulmalıdır.

Cumhuriyet Mahallesi yaya bölgesi, halkın Kale, Kapalı Çarşı, Vezir Han, Hunat Hatun Camii ve Külliyesi gibi tarihi kent merkezinde bulunan birçok tarihi yapıya ve mekâna güvenli ve doğrudan ulaşımı

\section{Kaynaklar}

Bayraktar, A., Aslanboğa, İ., Özkan, B., Güney, A., ve Türkyılmaz, B.1987, İzmir Kenti İçinde Halkın Açık Alan Gereksinimini Karşılamak Amacı İle Bazı Yol Ve Meydanların Taşı Trafiğinden Arındırılması Olanakları Üzerinde Araştırmalar. Ege Üniversitesi Araştırma Fonu Proje No:063, Bornova İzmir.

Cengiz, C., 2011. Bartın Hükümet Caddesi Yaya Bölgesi Tasarımının İrdelenmesi, Bartın Orman Fakültesi Dergisi, 13:20, s:80-89

Çağlar, N; 1992. Konut Alanları ve Alışveriş Merkezlerindeki Kent Sokaklarının Çağdaş Tasarımları Üzerine Bir Araștırma. A.Ü. Fen Bilimleri Enstitüsü Peyzaj Mimarlığı Anabilim Dalı, Doktora Tezi (Basılmamış), Ankara

Gülersoy, Z. 1992. Tarihi Şehir Merkezlerinin Gelişme Sürecinde Yayalaştırmanın Etkileri Beyoğlu Örneği. 2. Kentsel Tasarım ve Uygulamalar Sempozyumu, MSÜ Mimarlık Fakültesi, Şehir Planlama Bölümü, İstanbul.

Gültekin,B. 2007, Kent İçi Yolların, Yaya Kullanımına Yönelik Değerlendirilmesinde Çözümlemeli Bir Yaklaşım: Adana Örneği (Yüksek Lisans Tezi). Çukurova Üniversitesi Fen Bilimleri Enstitüsü Peyzaj Mimarlığı Anabilim Dalı, Adana.

Lorch, B. J. and Smith, M. J., 1993. Pedestrian Movement and the Downtown Enclosed Shopping Center. Journal of the American Planning Association, 59:1, 75-86.

Onay, N. 2005.Kamusal İç Mekan Ve Toplumsal Kimlik (Yüksek Lisans Tezi) İstanbul Teknik Üniversitesi Fen Bilimleri Enstitüsü Mimarlık Anabilim Dalı, İstanbul.

Özkan, B., E., Küçükerbaş, A., Kaplan, N. ve Aslan, N.,1993, Ülkemizde Peyzaj Planlama Calıșmalarında Tasarım Süreci Açısından Gözlenen Sorunların Bademler Mahmut Türkmenoğlu Parkı Örneğinde Çözümü Ve sağlayarak, tarihi dokunun kullanılarak korunmasına etki etmekte ve kentteki tarihi mirasa olumlu yönde katkı sağlamaktadır. Kayseri tarihi kent merkezinde uygulanan cephe yüzeyleri çalışması yaya bölgesi bütününde de yaygınlaştırılarak kent kimliği üzerinde olumlu etki yapması sağlanmalıdır.

$\mathrm{Bu}$ çalışma sonucunda gerek kent merkezindeki trafik yoğunluğunun azaltılması gerekse halkın yașam kalitesinin arttırılması için kent merkezinde benzer yaya bölgesi uygulamalarının düzenlenmesi gerekliliği ortaya çıkmıştır.

Olanakları Üzerinde Araştırmalar. E.Ü. Ziraat Fakültesi Peyzaj Mimarlığı Bölümü, S.29, Bornova, İzmir.

Roberston, K. A., 1999. Can Small-City Downtowns RemainViable? Journal of the American Planning Association, 65:3, 270-283.

Rubenstein, H. M., 1992, Pedestrian Malls, Streetscapesand Urban Spaces, John Wiley\&Sons, Inc.USA

Şenkaynak, P. 2010. Yaya Bölgelerinin Kentsel Peyzaj Planlama Açısından Önemi ve İstanbul'daki Bazı Örneklerin İncelenmesi. İstanbul Teknik Üniversitesi Fen Bilimleri Enstitüsü, Peyzaj Mimarlığı Anabilim Dalı, Yüksek Lisans Tezi, İstanbul

Şişman E. ve Kırzıoğlu I. 2002. Erzurum Kent Merkezinde Yaya Bölgesi Olabilecek Kent Mekan Birimlerinin Saptanmas1 ve Projelendirilmesi Üzerine Bir Araştırma. Trakya Üniversitesi Bilimsel araştırma Dergisi Cilt.3, Edirne

Şişman, E., ve Uyguner, B. 2009. Tekirdă Kent Merkezinde Kullanıcıların Yaya Bölgeleri Hakkındaki Görüşlerinin Belirlenmesi. Süleyman Demirel Üniversitesi Orman Fakültesi Dergisi. Seri: A, Sayı: 2,sayfa: 134146

Yıldırım, T., B., Özel, A.,E., Oktay, P., 2002. Yaya Bölgeleri Planlama Ve Tasarımı: Canakkale Çarşı Caddesi Yaya Yolu Örneği'nde, Uluslararası Trafik ve Yol Güvenliği Kongresi'nde Sunulan Bildiri, Gazi Üniversitesi, Ankara

Zafer, B.; 1996. Yaya Bölgeleri Planlama İlkeleri. E.Ü.Z.F. Peyzaj Mimarlığı Bölümü, İzmir.

Zafer, B.,1998. Aydın Germencik Belediyesi Yaya Bölgesi Tasarımı Üzerine Bir Araştırma. Ekoloji Dergisi, Sayı: 26, S.27-30, İzmir. 